\title{
DETERMINING OPTIMUM TILT ANGLES AND ORIENTATIONS OF PHOTOVOLTAIC PANELS IN NIŠ, SERBIA
}

\author{
T. Pavlović, Z. Pavlović, L. Pantić, Lj. Kostić \\ University of Niš, Faculty of Science and Mathematics, Niš, \\ P.O.Box. 224, st. Visegradska 33, Serbia
}

\begin{abstract}
Performance of photovoltaic (PV) solar module is affected by its orientation and its tilt angle with horizontal plane. These two parameters change the amount of solar energy received by the surface of the PV module. In this experiment the rotational solar module was positioned in the predefined angles. The solar module was rotated towards the East, South and West and positioned for the angles $0^{\circ}, 30^{\circ}, 45^{\circ}, 60^{\circ}$ and $90^{\circ}$. In these positions the values of current, voltage, power and solar radiation intensity were measured. The optimum positions were determined as positions in which maximum values of solar intensity and maximum power were registered. In this experiment the effect of two-axis solar tracking on electrical energy gain was compared to the electrical energy gain of a fixed PV module. This study determined that PV module oriented towards the South gives the greatest value of electrical energy for the angle of $30^{\circ}$, which is the maximum registered value, so it represents the optimum fixed position for the PV module in August. PV module rotated for these chosen angles for the same day gives $24.78 \%$ more electrical energy compared to the PV module in optimal fixed position, South $30^{\circ}$. Increase in solar radiation of $28.76 \%$ results in the increase in power of $24.78 \%$.
\end{abstract}

Keywords: optimum tilt angle; PV system performance, PV system optimization.

\section{INTRODUCTION}

In contemporary architecture PV solar modules have been used more and more as facade elements for electricity generation. Solar modules are being installed on unglazed facades so as to enable their better esthetics and electricity generation.

Solar radiation data is usually measured in the form of global radiation on a horizontal surface at the concerned latitude. Flat-plate collectors are tilted so that they capture maximum radiation. Since the flat-plate solar collectors are positioned at an angle to the horizontal, it is necessary to calculate the optimum tilt angle which maximizes the amount of collected energy. It is generally known that in the northern hemisphere, the optimum collector orientation is South facing and that the optimum tilt depends on the latitude and the day of the year. In winter months, the optimum tilt is greater (usually latitude $+15^{\circ}$ ), whilst in summer months the optimum tilt is lower (usually latitude $-15^{\circ}$ ) [1]. There are many papers in the literature which make different recommendations for the optimum tilt, based only on the latitude [2]. In practice, a collector plate is usually oriented South facing and at a fixed tilt which is set to maximize the average energy collected over the year.
Orientation of the collector is described by its azimuth and tilt angles. Generally, systems installed in the northern hemisphere are oriented toward south and tilted at a certain angle.[3] Many investigations have been carried out to determine the best tilt angle for such systems. For example, $\varphi+20^{\circ}[4], \varphi+10^{\circ}$ [5], $\varphi-10^{\circ}[6]$, whereas some researchers suggest two values for the tilt angle, one for summer and the other for winter, such as $\varphi \pm 20^{\circ}$ [7], $\varphi \pm 8^{\circ}$ [8], $\varphi \pm 5^{\circ}$ [9], where $\varphi$ is the latitude, "+" for winter, and " -" for summer.

The final aspect to consider when deciding on array orientation is the incorporation in the support structure. For building-integrated applications, the system orientation is also dictated by the nature of the roof or façade in which it is to be incorporated. It may be necessary to trade off the additional output from the optimum orientation against any additional costs that may be incurred to accomplish this. The aesthetic issues must also be considered [10].

When considering yearly average maximum output power the photovoltaic modules tilt angle should equal local latitude. Accurate and maximum energy output of larger systems should be based on exact calculations, because energy output is influenced by different factors, such as local climatic conditions (solar radiation availability in different sea-

*Corresponding author: pavlovic@pmf.ni.ac.rs 
sons, local cloudiness or fogginess in winter, temperature and so on) [11].

The period of November to March is very critical as these months correspond to the winter season for northern hemisphere when the amount of solar radiation falling over the globe is reduced. Since changing the tilt angle to its daily and monthly optimum values throughout the year does not seem to be practical, changing the tilt angle seasonally (once in a period of three months) seems reasonable [12].

If we take in consideration the climate in Niš region, the amount of the solar radiation, as well as the number of sunny days, then the best period to use solar energy in this region is from April till the end of October. For this latitude, the optimum tilt angle should be determined for this period.

\section{EXPERIMENTAL SETUP}

The experiment was conducted in Solar Energy Laboratory of the Faculty of Science and Mathematics, University of Niš. Niš is a city in, situated at the $43^{\circ} 19^{\prime \prime} \mathrm{N}$ and $21^{\circ} 54^{\prime \prime} \mathrm{E}$, with moderate and continental climate. Serbia has yearly average of 272 sunny days and yearly average total sunshine duration of $2300 \mathrm{~h}$.

The aim of the experiment was to determine $t$ he amount of electrical energy generated by solar module as a facade element in relation to its tilt angle and orientation.

A Siemens solar module, SM 55, with monocrystal silicon solar cells, with dimensions $31 \times 125 \mathrm{c}-$ $\mathrm{m}^{2}$, with maximum power $55 \mathrm{~W}$, for the normal solar radiation intake intensity of $1000 \mathrm{~W} / \mathrm{m}^{2}$, at temperature $t=25^{\circ} \mathrm{C}$, was used in the experiment, as shown in Figure 1.

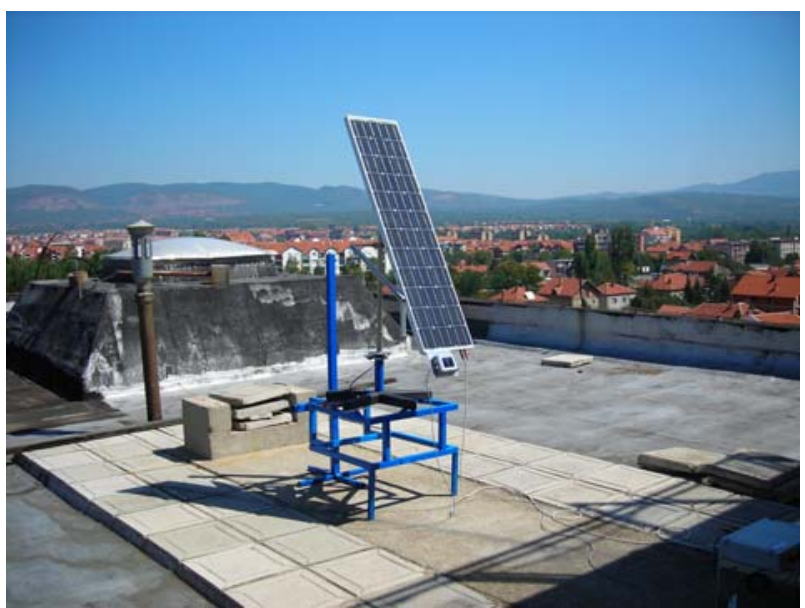

Figure1. Solar module, SM 55, on a revolving pedestal

For the measurement of current/voltage characteristics a KLA device that measures solar radiati- on intensity was used. Solar radiation intensity was measured in the plane of the solar module. At the same time solar radiation intensity was measured by means of Davis meteorological weather station.

A scheme of rotational solar module on revolving pedestal is shown in Fig.2.

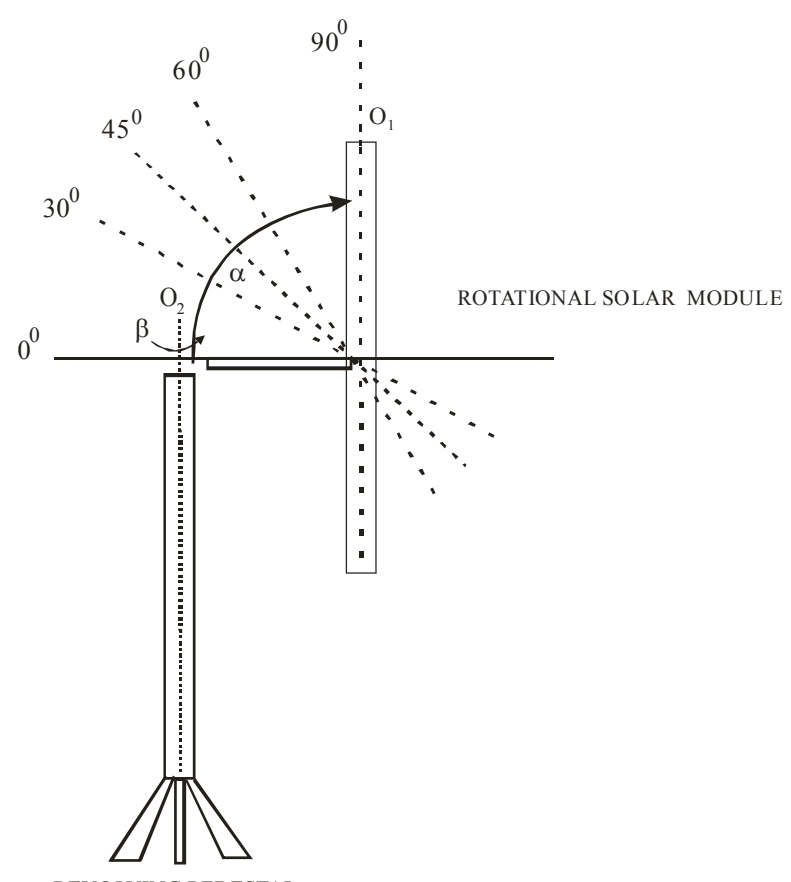

REVOLVING PEDESTAL

Figure 2. A scheme of rotational solar module on revolving pedestal

Solar module was installed on a revolving pedestal, with the rotational axis $\mathrm{O}_{2}$, which enables changing of the position of the solar module from east to west (angle $\beta$ from $0^{\circ}$ to $180^{\circ}$ ). By means of suitable mechanism a position of solar module can be changed around the axis in relation to horizontal plane for the angle $\alpha$ (from $0^{\circ}$ to $90^{\circ}$ ).

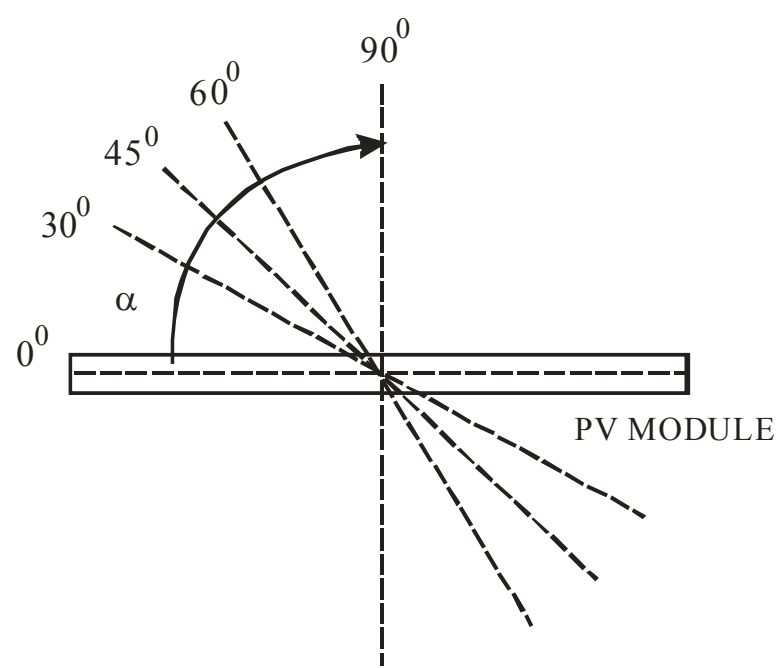

Figure 3. Position of solar module for chosen angles for which current/voltage characteristics and solar radiation intensity were measured 
In this experiment the rotational solar module was positioned in the predefined angles. On each full hour, from $8 \mathrm{am}$ till $5 \mathrm{pm}$, the solar module was rotated towards the East, South and West and positioned for the angles $0^{\circ}, 30^{\circ}, 45^{\circ}, 60^{\circ}$ and $90^{\circ}$. In these positions the values for current, voltage, power and solar radiation intensity were measured. Then solar module was rotated towards the South and West and the procedure was repeated.

\section{RESULTS AND DISCUSSIONS}

Changes in obtained electrical energy during the day, depending on the position of solar module in relation to horizontal plane (angle $\alpha$ ),for all the above mentioned angles, for the true East $\left(\gamma=90^{\circ}\right)$, South $\left(\gamma=180^{\circ}\right)$ and West $\left(\gamma=270^{\circ}\right)$ are shown in figures 4,5 and 6 respectively.

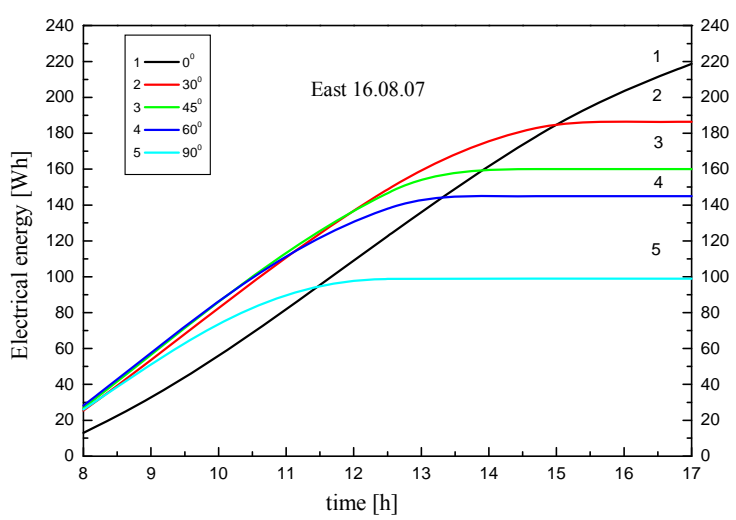

Figure 4 Change in the obtained electrical energy during the day, depending on the position of the solar module in relation to vertical plane (angle $\alpha$ ) for the East

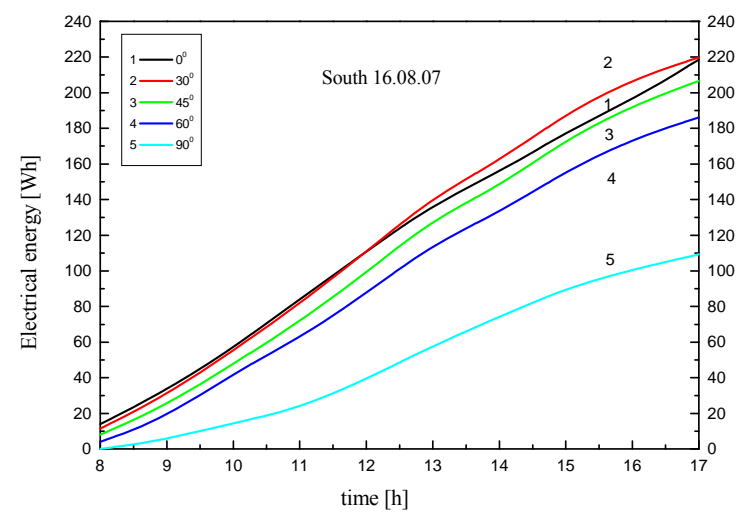

Figure 5. Change in the obtained electrical energy during the day, depending on the position of the solar module in relation to vertical plane (angle $\alpha$ ), for the South

Values of generated electrical energy for the chosen angles and positions are given in table 1 .

Based on Fig. 4, 5 and 6 and Table 1 it can be seen that the solar module oriented towards the east at an angle of $0^{\circ}$ generates electrical energy of
$218,63 \mathrm{Wh}$, which is maximal electrical energy for the East.

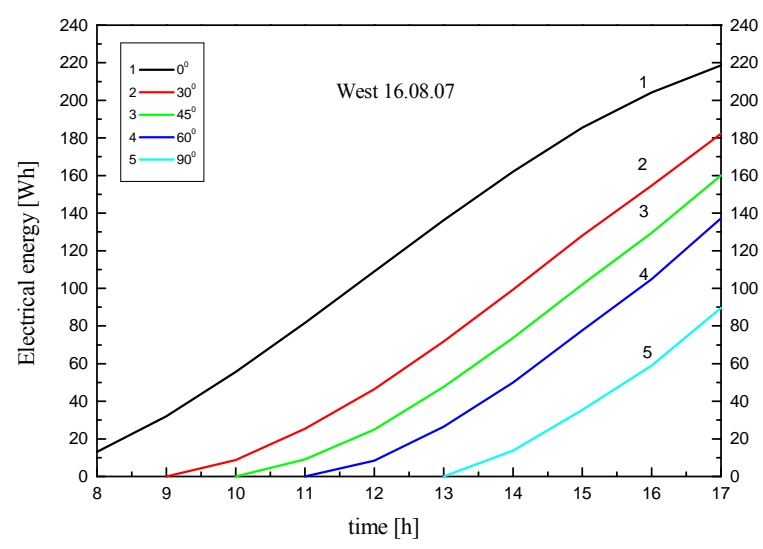

Figure 6. Change in the obtained electrical energy during the day, depending on the position of the solar module in relation to vertical plane (angle $\alpha$ ), for the West

Table 1. Values of generated electrical energy for the chosen angles and positions

\begin{tabular}{|c|c|c|c|}
\hline ANGLE & EAST [Wh] & $\begin{array}{c}\text { SOUTH } \\
{[\mathrm{Wh}]}\end{array}$ & $\begin{array}{c}\text { WEST } \\
{[\mathrm{Wh}]}\end{array}$ \\
\hline $0^{0}$ & 218,63 & 218,63 & 218,63 \\
\hline $30^{0}$ & 186,41 & $\mathbf{2 1 9 , 8 1}$ & 182,25 \\
\hline $45^{0}$ & 160,09 & 206,63 & 160,03 \\
\hline $60^{0}$ & 144,91 & 186,15 & 137,22 \\
\hline $90^{0}$ & 98,96 & 109,36 & 89,58 \\
\hline
\end{tabular}

Solar module oriented towards the South gives the greatest value for electrical energy for the angle of $30^{\circ}$ of $219.81 \mathrm{Wh}$, which is the maximum registered value for electrical energy.

It is visible from Table 1 that for fixed angles of $30^{\circ}, 60^{\circ}, 45^{\circ}$ and $90^{\circ}$ solar module oriented towards the South gives the greatest values of electrical energy and for the angle of $0^{\circ}$ the greatest value is given by a solar module oriented toward the East.

Values of obtained electrical energy for the East, South and West positions for the angles $0^{\circ}$, $30^{\circ}, 45^{\circ}, 60^{\circ}$ and $90^{\circ}$, are given in figures 7-10.

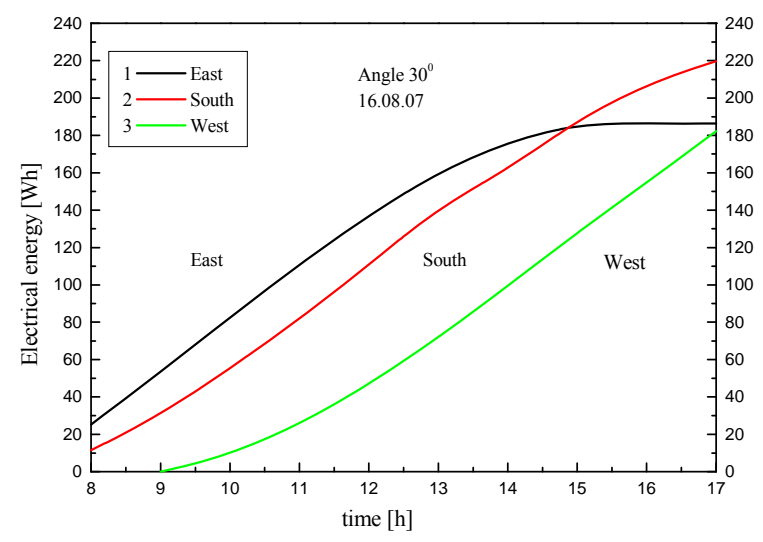

Figure 7. Values of obtained electrical energy, for the East, South and West for the angle $30^{\circ}$ 


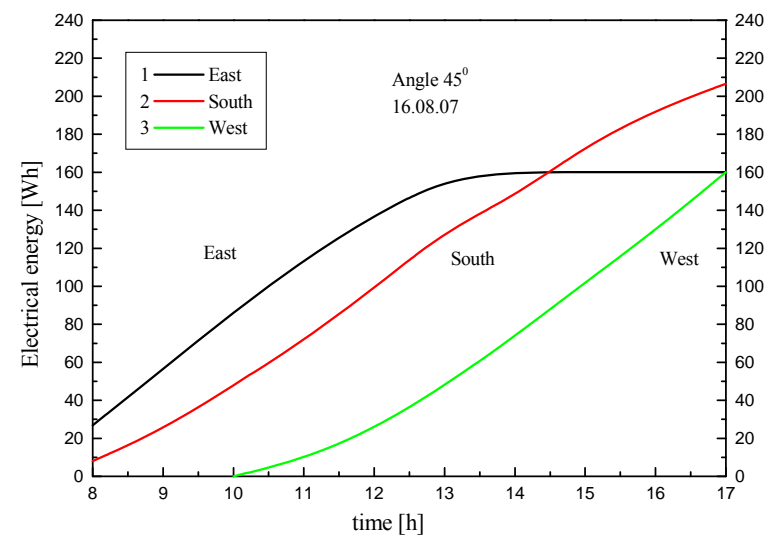

Figure 8. Values of obtained electrical energy, for the East, South and West for the angle $45^{\circ}$

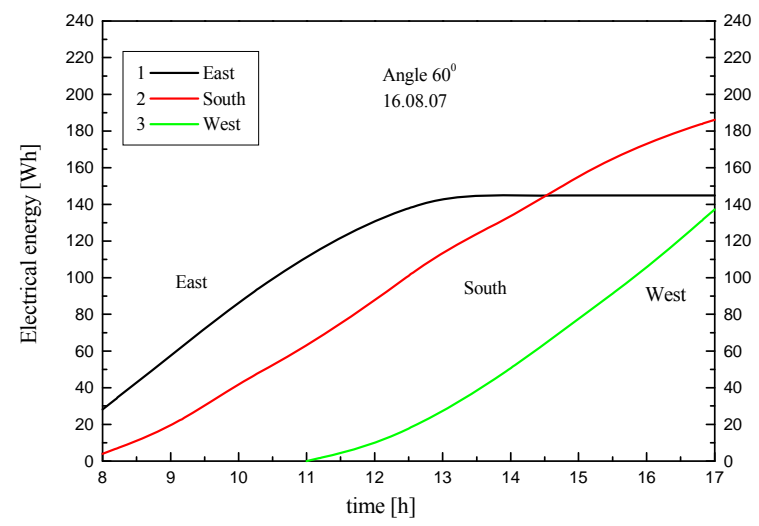

Figure 9. Values of obtained electrical energy, for the East, South and West for the angle $60^{\circ}$

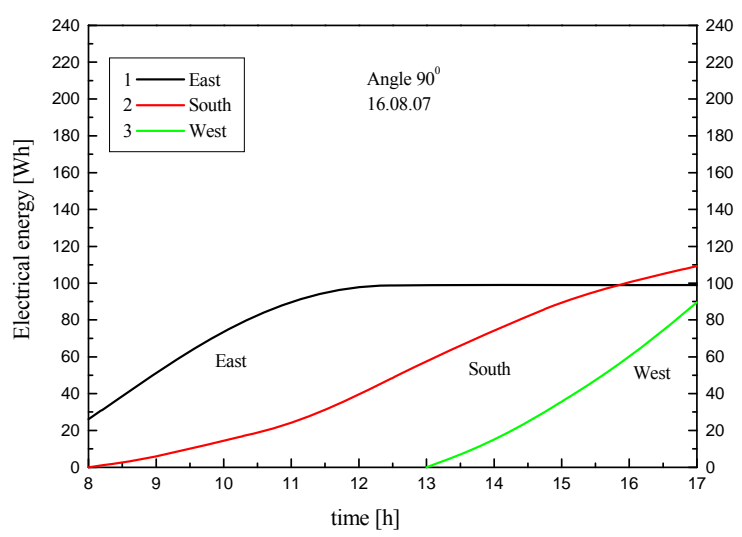

Figure 10. Values of obtained electrical energy, for the East, South and West for the angle $90^{\circ}$

Values of obtained electrical energy, for the East, South and West, for all predefined angles $\alpha$, are given in Fig. 11.

Values of daily solar radiation intensity measured by DAVIS meteorological station and KLA device are given in Table 2.

Based on Table 2 it can be seen that the total daily solar radiation intensity measured by KLA device is $6193 \mathrm{Wh} / \mathrm{m}^{2}$. Meteorological station in the sa- me period has measured intensity of $6238 \mathrm{Wh} / \mathrm{m}^{2}$. The difference between these two intensities is $0.8 \%$ which gives a possibility of data comparison.

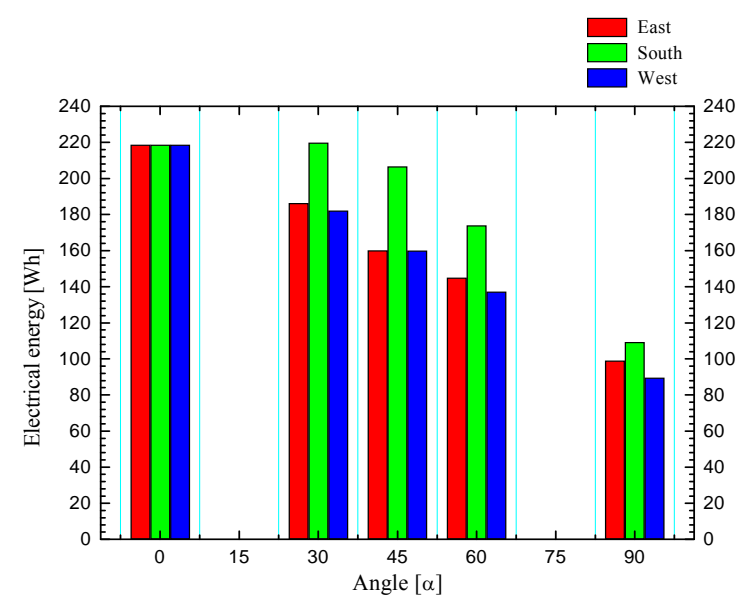

Figure 11. Values of obtained electrical energy, respectively for the East, South and West in for all chosen angles $\alpha$

Table 2. Values of daily solar radiation intensity measured by DAVIS meteorological station and KLA device

\begin{tabular}{|c|c|c|}
\hline & $\begin{array}{c}\text { Meteorological } \\
\text { station }\end{array}$ & $\begin{array}{c}\text { KLA } \\
\text { device }\end{array}$ \\
\hline $\begin{array}{c}\text { Solar radiation intensity } \\
\mathrm{Wh} / \mathrm{m}^{2}\end{array}$ & 6238 & 6193 \\
\hline
\end{tabular}

Referent position is horizontal one i.e. angle of $\alpha=0^{\circ}$ (that is a position in which meteorological station measures solar radiation intensity). Solar radiation intensity is measured by means of KLA device on each full hour for all chosen angles $\alpha$. Positions in which maximum values of intensity are registered, are taken for optimal positions.

Comparative solar radiation intensity measured by KLA device for referent and optimal position is given in Figure 12.

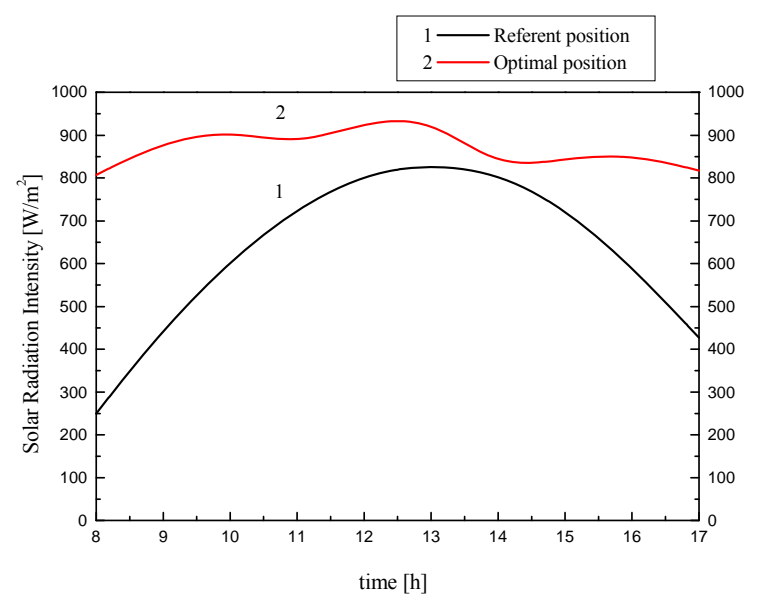

Figure 12. Comparative daily solar radiation intensity measured by KLA device for referent and optimal position 
Values of solar radiation intensity measured by KLA device for referent and optimal position are given in table 3 .

Table 3. Values of daily solar radiation intensity measured by KLA device for referent and optimal position

\begin{tabular}{|c|c|c|}
\hline & $\begin{array}{c}\text { KLA device } \\
\text { (referent } \\
\text { position) }\end{array}$ & $\begin{array}{c}\text { KLA device } \\
\text { (optimal } \\
\text { position) }\end{array}$ \\
\hline $\begin{array}{c}\text { Solar radiation } \\
\text { intensity } \mathrm{Wh} / \mathrm{m}^{2}\end{array}$ & 6193 & 8692 \\
\hline
\end{tabular}

Based on Table 3 it can be seen that the total intensity of solar radiation measured by KLA in the referent position is $6193 \mathrm{Wh} / \mathrm{m}^{2}$, while KLA in optimal position has measured intensity of $8692 \mathrm{Wh} / \mathrm{m}^{2}$. Difference between these two intensities is $28,76 \%$.

Solar radiation intensity for solar module in optimal position is given in table 4 .

Table 4 shows that the maximal solar radiation intensity measured is $30^{\circ}$ for the South at $13 \mathrm{~h}$, which corresponds to the solar noon.

Total values for power obtained by solar module in optimal position are given in table 5 .

In Table 5 a slight deviation in an increase of power is recorded. The maximum one is registered for the position South $30^{\circ}$ and corresponds to the maximum of the solar radiation intensity and the other is recorded for the position West $30^{\circ}$. This second power maximum shows that these chosen angles do not show real movement of the Sun during the day.

Table 4. Solar radiation intensity for solar module in optimal position

\begin{tabular}{|c|c|c|}
\hline TIME & $\begin{array}{c}\text { OPTIMAL } \\
\text { POSITION }\end{array}$ & $\begin{array}{c}\text { SOLAR RADIATION } \\
\text { INTENSITY Wh } / \mathrm{m}^{2}\end{array}$ \\
\hline 8 & East $60^{\circ}$ & 807 \\
\hline 9 & East $60^{\circ}$ & 985 \\
\hline 10 & East $45^{\circ}$ & 876 \\
\hline 11 & East $30^{\circ}$ & 931 \\
\hline 12 & South $30^{\circ}$ & $\mathbf{9 4 2}$ \\
\hline 13 & South $\mathbf{3 0}^{\circ}$ & 820 \\
\hline 14 & West $30^{\circ}$ & 846 \\
\hline 15 & West $30^{\circ}$ & 856 \\
\hline 16 & West $60^{\circ}$ & 817 \\
\hline 17 & West $60^{\circ}$ & 8692 \\
\hline
\end{tabular}

Table 5. Values of power obtained by solar module in optimal position

\begin{tabular}{|c|c|c|}
\hline Time & $\begin{array}{c}\text { Direction and } \\
\text { angle of maximal } \\
\text { power } \\
\text { (optimal position) }\end{array}$ & Power (W) \\
\hline 8 & East $60^{0}$ & 28,20 \\
\hline 9 & East $45^{0}$ & 29,67 \\
\hline 10 & East $45^{0}$ & 30,00 \\
\hline 1 & East $30^{0}$ & 28,31 \\
\hline 12 & South $30^{0}$ & 29.18 \\
\hline 13 & South $30^{0}$ & 30.80 \\
\hline 14 & West $30^{0}$ & 27,60 \\
\hline 15 & West $30^{0}$ & 28,69 \\
\hline 16 & West $45^{0}$ & 27,44 \\
\hline 17 & West $60^{0}$ & 32,33 \\
\hline Total & & 292,22 \\
\hline
\end{tabular}

These angles were not chosen to represent the movement of the Sun during the day; they just represent angles which can be considered when using solar PV modules as a façade element.

If solar module is rotated each full hour in the optimal position one would generate the total energy of 292,22 Wh. If we consider optimal fixed point South $30^{\circ}$ which generates energy of $219,81 \mathrm{Wh}$ then the rotation panel would generate $24,78 \%$ more electrical energy.

\section{CONCLUSION}

On the basis of the above mentioned one can conclude that:

1) Solar module oriented towards the South gives the greatest values of electrical energy for all the chosen angles.

2) Solar module oriented towards the South for the angle of $30^{\circ}$ generates the greatest registered value for electrical energy. This is an optimal tilt angle in the summer.

3) Generated electrical energy for solar module oriented towards the South $30^{\circ}$ and East (West) for the angle $0^{\circ}$ differ by $0,54 \%$.

4) Generated electricity for solar module oriented towards the East, South and West for angle $0^{\circ}$ is the same.

5) Solar module rotated for these chosen angles for the same day gives $24,78 \%$ more energy compared to the solar module in optimal fixed position South $30^{\circ}$.

6) If the facade is oriented towards South, which is an optimal solution, the solar module should be installed at an angle of $30^{\circ}$.

7) If we consider installation of solar modules towards the East (West) the greatest values of 
energy are obtained for the horizontal position i.e. the angle of $0^{\circ}$. In this case PV modules are installed on the flat roof.

8) An increase in solar radiation of $28,76 \%$ results in the increase in power of $24,78 \%$.

9) The best orientation for solar modules in Niš, during the summer period, is toward the South installed at an angle of $30^{\circ}$. That is latitude $-13^{\circ}$.

\section{REFERENCES}

[1] D. Ibrahim, Optimum tilt angle for solar collectors used in Cyprus, Renewable Energy 6, 7 (1995) 813-19.

[2] M. Iqbal, Optimum collector slope for residential heating in adverse climates. Solar Energy 22 (1979) 77-9.

[3] A. M. Shariah, A. Al-Akhars, I. A. AlOmari, Optimizing the tilt angle of solar collectors, Renewable Energy 26 (2002) 587-98.

[4] H. C. Hottel, Performance of flat-plate energy collectors. In: Space Heating with Solar Energy, Proc. Course Symp. Cambridge: MIT Press, 1954
[5] J. Kern and L. Harris, On the optimum tilt of a solar collector. Solar Energy (1975) 17.97.

[6] H. Hyewood, Operating experience with solar water heating. Journal of the Institution of Heating and Ventilation Engineers 39 (1971) 63-9.

[7] H. Yellott, Utilization of sun and sky radiation for heating cooling of buildings. ASHRAE Journal 15 (1973) 31.

[8] G. Lewis, Optimum tilt of solar collectors. Solar and Wind Technology 4 (1987) 407.

[9] H. P. Garp, G. L. Gupta. In: Proceedings of the International Solar Energy Society, Congress, New Delhi 1978, 1134.

[10] N. M. Pearsall and R. Hill, Photovoltaic modules, systems and applications, Ch 15 edMA3.doc (2001).

[11] Solar radiation estimation and site analysis; http://www.pvresources.com/en/location.php

[12] M. A. M. Yakup, A. Q. Malik., Optimum tilt angle and orientation for solar collector in Brunei Darussalam. Renewable Energy 24 (2001) 223-34.

\section{ОДРЕЪИВАЊЕ ОПТИМАЛНИХ УСЛОВА НАГИБА У ОРИЈЕНТАЦИЈИ ФОТОНАПОНСКИХ ПЛОЧА У НИШУ, СРБИЈА}

Сажетак: Перформансе фотонапонског $(Ф Н)$ соларног модула зависе од његове оријентације и његовог нагиба у односу на хоризонталну плочу. Због ова два параметра мијења се количина соларне енергије коју прима површина ФН модула. У овом експерименту поставили смо ротациони соларни модул под унапријед дефинисане углове. Соларни модул је био ротиран према истоку, југу и западу и постављан на углове од $0^{\circ}, 30^{\circ}$, $45^{\circ}, 60^{\circ}$ и $90^{\circ}$. У овим позицијама мјерене су вриједности струје, напона, снаге и соларног исијавања. Одређиване су оптималне позиције као позиције у којима су забиљежене максималне вриједности соларног интензитета и максимална снага. У овом експерименту ефекат двоосовинског соларног праћења повећања електричне енергије упоређиван је са повећањем електричне енергије фиксног ФН модула. На основу овог испитивања утврђено је да ФН модул оријентисан према југу даје највећу вриједност електричне енергије при углу од $30^{\circ}$, што је максимална забиљежена вриједност, те представља оптималну фиксну позицију за ФН модул у мјесецу августу. ФН модул ротиран под овим изабраним угловима током истог дана даје $24,78 \%$ више електричне енергије у поређењу са ФН модулом у оптималном фиксном положају, југ $30^{\circ}$. Повећање соларног исијавања од $28,76 \%$ резултује повећањем снаге од $24,78 \%$.

Кључне ријечи: оптимални углови нагиба; перформанса ФН система, оптимизација ФН система. 